JOB CHANGES AND

INDIVIDUAL-JOB SPECIEIC

WAGE DYNAMICS

Laura Hospido

Documentos de Trabajo.

N. 0907

BANCODE ESPANA

2009

Eurosistema 
JOB CHANGES AND INDIVIDUAL-JOB SPECIFIC WAGE DYNAMICS 


\section{JOB CHANGES AND INDIVIDUAL-JOB SPECIFIC}

WAGE DYNAMICS $\left.{ }^{*}\right)$

Laura Hospido

BANCO DE ESPAÑA

$\left(^{*}\right)$ Thanks to Manuel Arellano, Cristian Bartolucci, Stéphane Bonhomme, Jean-Marc Robin and the seminar participants at the EEA-ESEM2008 meeting in Milan and the 2008 Simposio de Análisis Económico in Zaragoza. All errors are mine. The opinions and analyses are the responsibility of the author and, therefore, do not necessarily coincide with those of the Bank of Spain or the Eurosystem. 
The Working Paper Series seeks to disseminate original research in economics and finance. All papers have been anonymously refereed. By publishing these papers, the Banco de España aims to contribute to economic analysis and, in particular, to knowledge of the Spanish economy and its international environment.

The opinions and analyses in the Working Paper Series are the responsibility of the authors and, therefore, do not necessarily coincide with those of the Banco de España or the Eurosystem.

The Banco de España disseminates its main reports and most of its publications via the INTERNET at the following website: http://www.bde.es.

Reproduction for educational and non-commercial purposes is permitted provided that the source is acknowledged.

( ) BANCO DE ESPAÑA, Madrid, 2009

ISSN: 0213-2710 (print)

ISSN: 1579-8666 (on line)

Depósito legal: M. 21150-2009

Unidad de Publicaciones, Banco de España 


\section{Abstract}

This paper develops an error components model that is used to examine the impact of job changes on the dynamics and variance of individual log earnings. I use data on work histories drawn from the Panel Study of Income Dynamics (PSID), that makes possible to do the distinction between voluntary an involuntary job-to-job changes. The potential endogeneity of job mobility in relation to earnings es circumvented by means of an instrument variable estimation method that also allows to control for unobserved individual-job specific heterogeneity.

Keywords: Panel data, dynamic models, individual-job specific fixed effects, job changes, individual wages.

JEL classification: C23, J31. 


\section{Introduction}

A large literature on labour economics has focused on the determinants of wages. On the one hand, studies based on the human capital theory (Becker, 1975) examine the impact of general experience on wages, ignoring job mobility. On the other hand, studies based on job search and matching theories (Burdett, 1978; Jovanovic, 1979) or purely learning by doing (Rosen, 1972), look at the effect of job specific human capital on wages. This literature has focused on estimating the returns to experience and tenure $^{1}$, trying to control for the endogeneity of tenure using different methods ${ }^{2}$.

Another related literature on earnings dynamics has modelled and estimated the heterogeneity and time series properties of individual wage processes ( Lillard and Willis, 1978; MaCurdy, 1982; Abowd and Card, 1989; Meghir and Pistaferri, 2004), but many have ignored job mobility and the distinction between dynamics within and between jobs. However, job mobility may affect the mean but also the shape of the distribution of earnings and, moreover, this effect may last for several periods after the job change.

The relationship between job mobility and earnings dynamics is economically relevant as, for instance, transitions into poverty may increase dramatically following a job loss, but also because job mobility may have an equalizing role over the life-cycle inequality, depending on whether workers are more o less able to improve their economic situation by changing jobs.

In Hospido (2009), I consider a model for the heterogeneity and dynamics of the conditional mean and the conditional variance of individual wages. In the empirical analysis - conducted on data drawn from the Panel Study of Income Dynamics (PSID) - I find that it is important to account for individual unobserved heterogeneity and dynamics also in the conditional variance, and that the dynamics are driven by job mobility. In line with those results, this paper develops a model that explicitly considers job changes in the dynamics of wages and in the heterogeneity pattern. In particular, the specification proposed has two

\footnotetext{
${ }^{1}$ See, for example, Altonji and Shakotko (1987), Topel (1991), Topel and Ward (1992), Neal (1995), Altonji and Williams (1997), Dustmann and Meghir (2005), among others.

${ }^{2}$ A first group of studies uses a single wage equation and then applies instrument variable or control function methods to control for the endogeneity bias (Altonji and Shakotko, 1987; Topel, 1991; Altonji and Williams, 1997; Dustmann and Meghir, 2005). A second approach exploits information on firm closures (Neal 1995, Bonhomme and Jolivet, 2006). A third group suppose that workers' mobility decisions produce realized wage rates that are not random samples of the offered wage rates and estimate the returns to tenure taking into account the sample selection process (Topel, 1986; Marshall and Zarkin, 1987). Finally, other studies explicitly specify a simultaneous equation model with wage rate and job tenure as dependent variables, based upon a model in which they are jointly determined (Lillard, 1999; Abowd and Kang, 2002; Bagger, 2007; Amann and Klein, 2007).
} 
different parameters to capture dynamics within jobs and across jobs, and the unobserved heterogeneity shows a richer pattern as well, composed of both individual and job-specific effects.

As pointed out by Low et al. (2008), it is important to distinguish between movements in earnings that reflect choice and those which reflect uncertainty. Those authors address this issue by allowing for endogenous labour supply and job mobility which implies that a proportion of earnings fluctuations, usually interpreted as risk, are in fact attributed to choice. Here, the potential endogeneity of job mobility in relation to earnings is circumvented using an instrument variable estimation method that controls for individual and job-specific unobserved heterogeneity.

A recent empirical literature (Stevens, 2001; Leonardi, 2003) examines the contribution of job changes to the increasing male earnings inequality in the United States since the 1970. Following Gottschalk and Moffitt's 1994 and 1995 studies, these references have focused on the transitory component of the earnings variance (earnings instability). The problem with the models that they consider is that they are incapable of incorporating the effect of job mobility on permanent income because they parameterize permanent income as a fixed individual effect. However, this is a simplification as job mobility may also affect permanent income. In this paper, differently to Berry et al. (1988), Stevens (2001), and Leonardi, 2003, I explicitly consider job-specific effects as well as individual unobserved characteristics, that is, the individual effects are time invariant whereas the job-specific or match effects change across jobs but remain constant within the same position ${ }^{3}$. Differently to Lillard (1999), Abowd and Kang (2002) and Low et al. (2008), I adopt a fixed effects perspective leaving the distribution for the unobserved heterogeneity components completely unrestricted and treating each effect as one different parameter to be estimated.

The paper contributes to the literature by more thoroughly describing the impact of job mobility on the dynamics and heterogeneity of individual wages than previous references. In particular, the proposed model: (i) permits that job changes may be correlated with individual and job specific unobserved characteristics, (ii) is agnostic regarding the distribution of these individual and job effects, (iii) can be estimated with no need to explicitly model the job mobility process, and (iv) allows us to calculate different components of the variance within and across jobs.

\footnotetext{
${ }^{3}$ The importance of match effects in explaining wages has been stressed by Topel and Ward (1992), Abowd et al. (1999), Postel-Vinay and Robin (2002) and Bonhomme and Jolivet (2006).
} 
In the empirical application, I use data on work histories drawn from the 1968-1993 PSID. These data allow me to establish the distinction between voluntary job-to-job changes (quits) and involuntary job-to-job changes (job losses). In the sample, once we control for individual and job-specific effects, the persistence within jobs is almost zero, whereas across jobs is significant but small. For the dynamics, the distinction between voluntary and involuntary transitions turns out to be irrelevant. However, this distinction matters in terms of risks. The estimated variance of the job-specific effects represents around one third of the variance for the individual fixed effects. However, if I consider a subsample that only includes involuntary job changes, the estimated variability across jobs increases up to two thirds with respect to the individual time-invariant component.

The rest of the paper is organised as follows. Section 2 describes the data. Section 3 presents the model. Section 4 explains the estimation strategy and section 5 shows the estimation results. Finally, section 6 concludes with a future research agenda.

\section{The Data}

The data come from the PSID for the period from 1968 to $1993^{4}$. The PSID began in 1968 by inteviewing over 5,000 families. Of these, about 3,000 families were representative of the US population as a whole (the core sample), and about 2,000 were low-income families (the Census Bureaus SEO sample). Thereafter, these same families have subsequently been interviewed every year, as have any new families formed from the original group of families ${ }^{5}$. The survey contains abundant information on individual characteristics, income and labour market status. The data set should follow individuals over a sufficiently long period of time to observe pre- and post- job changes earnings histories.

\footnotetext{
${ }^{4}$ Several changes have been implemented to the PSID since the mid-1990s. The most important is that the PSID switched to biannual interviewing in 1997. In addition, I exclude the 1994-1997 income files because, as explained by Kim et al. (2000), the continuity of the PSID data in those years was disrupted by a major revision of the survey that included a switch to computer-assisted telephone interviewing and to automated editing of the data, and changes in the structure of the income questions.

${ }^{5}$ A family member who moves out of a PSID family is eligible for interviewing as a separate family unit if he or she is a sample member and he or she is 18 years old or older and living in a different, independent household.
} 


\subsection{Sample Construction}

In the empirical analysis, I use the core sample. I restrict my study to heads of households ${ }^{6}$ since, during the sample period, survey questions regarding employment history are only asked to them ${ }^{7}$. In addition, to focus the analysis during the working life, I select males aged 25 to 55 , with no missing records on race, education, region of residence or, if appropriate, reason of job change. I drop the self-employed, those with topcoded wages, and those with less than 8 years of usable data on earnings. Finally, I have an unbalanced panel that contains 2,013 individuals and 27,845 observations from 1968 to $1992 .{ }^{8}$

Step-by-step details on sample selection are reported in Appendix A. Sample composition by year, individuals by number of observations and demographic characteristics are presented in Appendix B.

\subsection{Job Changes Definition}

A job change takes place when current tenure of the worker is less than a year and there is information available regarding the type of change. The type of change is defined by the answer to the question: "What happened to the job you had before - did the company go out of business, were you laid off, promoted, or what?". Therefore, I define a job change as an involuntary job separation or job loss in case of business or plant closing or due to being laid off or fired; and as quit, in case of voluntary change.

The question quoted above was only asked to individuals who report being with their present employer for less than twelve months (otherwise the question is skipped and coded as not applicable), so this make me feel confident regarding the variable tenure ${ }^{9}$. As pointed out by Polsky (1999), from 1984 to 1988 this question was asked to all respondents who reported that their current job started after January of the previous year. To correct for this possible inconsistency, no job change is reported for those with current tenure greater than one year.

The sample only includes job-to-job changes, because monthly calendar information, that would provide information regarding spells of unemployment lower than a year, is not available before 1984 .

\footnotetext{
${ }^{6} \mathrm{~A}$ household head is defined as the adult of the family. When there is more than one adult in the family, the PSID assigns the primary male adult as the household head.

${ }^{7}$ The same information is available also for wives only from 1979.

${ }^{8}$ In practice, I use information only until 1992 because, in every survey wave, the time reference for wage records is the previous year.

${ }^{9}$ Since the PSID does not collect information on specific employers, the identification of job changes in this data set has been quite controversial. Many of the difficulties related to measuring job tenure in the PSID were evaluated by Brown and Light (1992). The tenure question also switched from being coded in intervals prior to 1976 to being measured in months, and from asking about position tenure to employer tenure. In any case, these difficulties are not so important here since I am not interested in the exact value of the variable but if tenure is less or more than one year.
} 


\subsection{Descriptive Analysis of the Raw Data}

The descriptive analysis will emphasize a number of salient facts about job mobility and the relationship between this and earnings dynamics.

Job mobility Among the 2,013 sample individuals, there are 699 individuals (around 35 percent) who never change job, whereas the remaining individuals change at least once (on average they have 3.40 different jobs).

As pointed out by Topel and Ward (1992), the most prominent and widely documented facts about job mobility are that average rates of job changing decline with age or experience and, specially, with current job tenure. These facts are consistent with the predictions of job-matching and search models ${ }^{10}$ (Johnson, 1978; Burdett, 1978; Jovanovic, 1979).

Figure 1 shows those patterns in the sample. We can see how the probability of changing job decreases as age, or alternatively tenure, increases.

Figure 1. Probability of Job Change
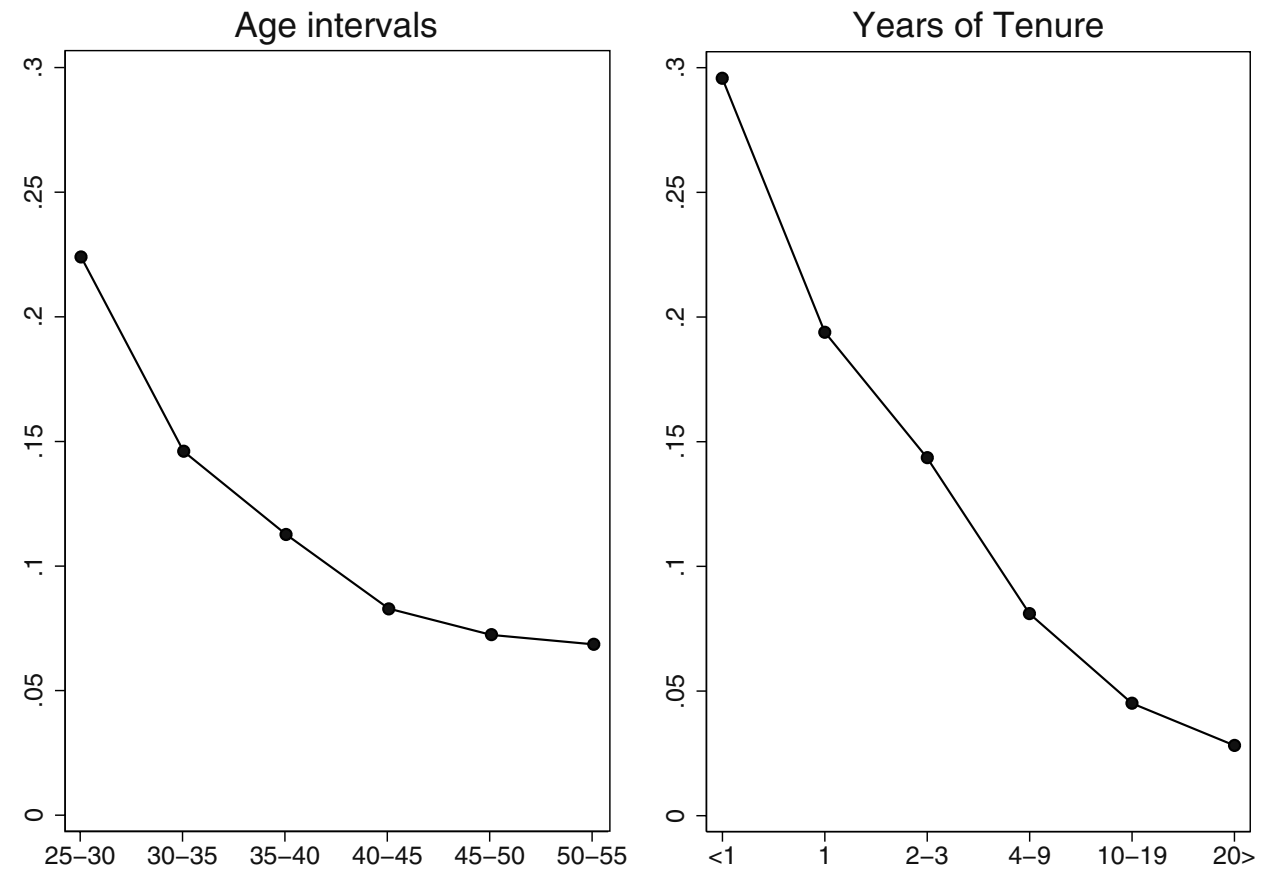

\footnotetext{
${ }^{10}$ In a matching model, job mobility is the consequence of a voluntary change to a better position where the worker is more productive and receives a higher pay. Search models are based on the existence of imperfect information. In these models, jobs are experience goods. As time goes by, the firm acquires more information and it can adjust the salary better. Under this approach, job mobility is the result of poor matchings looking for a better chance.
} 
Regarding vintage effects, it is less clear if people entering the labor market more recently have patterns of labor mobility different from those of earlier cohorts. Table 1 presents the distribution of jobs by birth cohort. The 1921-1941 cohort contains a larger proportion of individuals who only have one job than individuals born between 1941-1960. Although sample selection may be relevant, since workers are more exposed to job changes as they grow older and more recent entrants are less likely to be observed in higher-order jobs, the results in the table suggest an increase in job instability for the most recent cohort in the sample.

Table 1. Distribution of Individuals over Jobs by Birth Cohort (percent)

\begin{tabular}{lcccccccc}
\hline & \multicolumn{7}{c}{ Maximum Number of jobs } \\
\cline { 2 - 9 } & 1 & 2 & 3 & 4 & 5 & 6 & $<6$ & $\mathrm{~N}$ \\
\hline \hline All & 37.70 & 22.16 & 17.09 & 9.34 & 6.01 & 3.73 & 3.97 & 2,013 \\
Before 1941 & 51.12 & 21.67 & 13.60 & 5.53 & 3.29 & 2.24 & 2.55 & 669 \\
1941 on & 31.03 & 22.40 & 18.82 & 11.24 & 7.37 & 4.46 & 4.68 & 1,344 \\
\hline Note: Percentages are computed on total number of individuals in the sample, $N$. \\
Each cell represents the proportion of individuals who had at most $x$ jobs.
\end{tabular}

With respect to the reason of change, if we look at average rates of job changing by cohorts we find that younger cohorts of workers are more likely to be laid off from their jobs than older cohorts but the difference is bigger in case of quit. More striking is the comparison across skill groups (see Figure 2).

Figure 2. Probability of Job Change
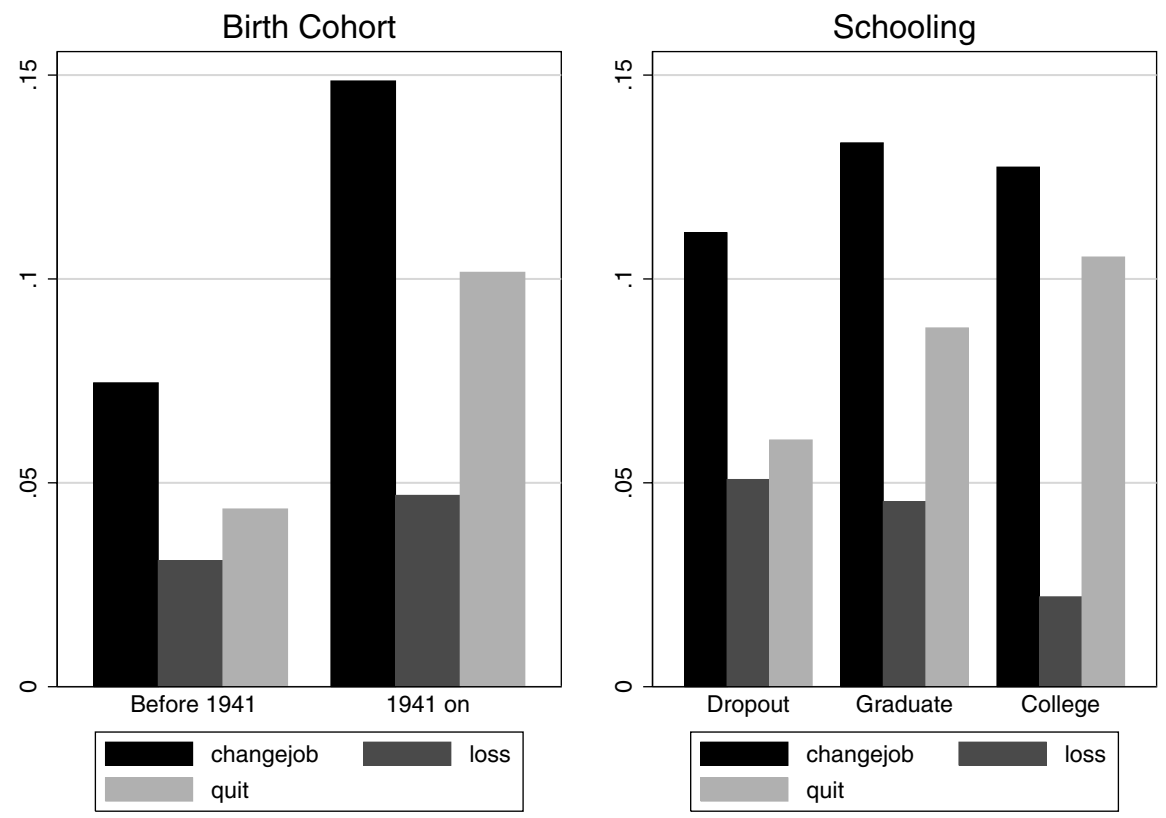
For all groups the main reason for leaving job is quitting, but the difference with respect to layoff is more important for graduate and - specially - for college people than for dropouts.

Job mobility and earnings dynamics In order to get a first impression of the impact that job changes have over the evolution of earnings, I calculate the cross-sectional sample correlations for consecutive logwage observations on years when no-change, a job loss or a job quit has happened ${ }^{11}$. Table 2 summarizes those calculations that work also as a check for the definitions above. As we would expect, when a job change occurs the correlation diminish, and that reduction is bigger in case of job loss than in case of a voluntary job change.

Table 2. Sample Correlations across Individuals

\begin{tabular}{cccc}
\hline Correlations & No-change at time $t$ & Job loss at time $t$ & Job quit at time $t$ \\
\hline \hline$\left(w_{i t-3}, w_{i t-2}\right)$ & 0.902 & 0.863 & 0.873 \\
$\left(w_{i t-2}, w_{i t-1}\right)$ & 0.905 & 0.689 & 0.853 \\
$\left(w_{i t-1}, w_{i t}\right)$ & 0.903 & 0.590 & 0.748 \\
$\left(w_{i t}, w_{i t+1}\right)$ & 0.886 & 0.816 & 0.893 \\
$\left(w_{i t+1}, w_{i t+2}\right)$ & 0.866 & 0.817 & 0.857 \\
\hline
\end{tabular}

Table 3 displays average annual wage growth for workers within jobs and between jobs by type of exit. Within-job annual wage growth is lower than between-job annual wage growth in case of voluntary transitions. In case of job loss, real wages drop. I find the same qualitative patterns among different demographic groups.

Table 3. Sample Wage Annual Growth

\begin{tabular}{lccc}
\hline Wage growth & Within job & Job loss & Job quit \\
\hline \hline All & 0.010 & -0.101 & 0.035 \\
& $(0.271)$ & $(0.716)$ & $(0.444)$ \\
\hline Wokers $<35$ & 0.021 & -0.022 & 0.075 \\
years old & $(0.268)$ & $(0.725)$ & $(0.398)$ \\
Wokers $\geq 35$ & 0.002 & -0.164 & 0.013 \\
years old & $(0.272)$ & $(0.703)$ & $(0.503)$ \\
\hline Dropout & 0.001 & -0.113 & 0.012 \\
& $(0.332)$ & $(0.810)$ & $(0.506)$ \\
Graduate & 0.009 & -0.098 & 0.076 \\
& $(0.258)$ & $(0.661)$ & $(0.480)$ \\
College & 0.024 & -0.074 & 0.1022 \\
& $(0.203)$ & $(0.680)$ & $(0.457)$ \\
\hline
\end{tabular}

Note: standard deviation in parentheses.

\footnotetext{
${ }^{11}$ Nominal annual earnings are deflated by the GNP Personal Consumption Expenditure Deflator (base 1992).
} 
As pointed out by Dustmann and Meghir (2005), the fact that within-job wage growth is lower than between-job wage growth does not imply that, on average, job quitters have higher wages than stayers. As they did, I regress log wages on dummies for the number of jobs workers have held up to then, also including age and year dummies.

Table 4. Log wages on number of jobs

\begin{tabular}{lcccccc}
\hline $\begin{array}{l}\text { Number } \\
\text { of jobs }\end{array}$ & \multicolumn{3}{c}{ OLS } & \multicolumn{3}{c}{ Fixed effects } \\
\cline { 2 - 7 } & All & $\begin{array}{c}\text { Voluntary } \\
\text { movers }\end{array}$ & $\begin{array}{c}\text { Involuntary } \\
\text { movers }\end{array}$ & All & $\begin{array}{c}\text { Voluntary } \\
\text { movers }\end{array}$ & $\begin{array}{c}\text { Involuntary } \\
\text { movers }\end{array}$ \\
\hline \hline 2 & -0.017 & 0.069 & -0.371 & 0.020 & 0.082 & -0.177 \\
& $(-1.89)$ & $(7.13)$ & $(-20.45)$ & $(2.84)$ & $(10.80)$ & $(-11.90)$ \\
3 & -0.044 & 0.128 & -0.442 & 0.068 & 0.195 & -0.146 \\
& $(-3.94)$ & $(9.00)$ & $(-16.23)$ & $(7.45)$ & $(17.92)$ & $(-6.93)$ \\
4 & -0.076 & 0.146 & -0.597 & 0.074 & 0.227 & -0.329 \\
& $(-5.18)$ & $(7.13)$ & $(-9.86)$ & $(6.29)$ & $(14.92)$ & $(-7.81)$ \\
5 & -0.139 & 0.119 & -0.740 & 0.076 & 0.258 & -0.338 \\
& $(-6.67)$ & $(3.45)$ & $(-6.25)$ & $(5.07)$ & $(11.66)$ & $(-4.68)$ \\
6 & -0.175 & 0.282 & -1.305 & 0.118 & 0.356 & -1.166 \\
& $(-6.41)$ & $(5.42)$ & $(-2.41)$ & $(6.31)$ & $(11.00)$ & $(-4.37)$ \\
7 & -0.391 & 0.110 & -0.997 & 0.028 & 0.268 & -0.841 \\
& $(-9.62)$ & $(1.44)$ & $(-1.84)$ & $(1.07)$ & $(6.03)$ & $(-3.15)$ \\
\hline
\end{tabular}

Note: t-ratios in parentheses. All regressions include age and time dummies.

Estimates for the first seven jobs, reported in the first column of Table 4, indicate that workers with more jobs have lower wages. Once I include individual fixed effects in the regression (column 4), the number of jobs is positively related with wages. In fact, if I exclude from the sample movers who transit only through job loss (columns 2 and 5), I obtain a positive relationship between number of jobs and wages. On the contrary, if I exclude those who change voluntary (columns 3 and 6), I obtain that workers with more jobs have lower wages even after including individual fixed effects.

\section{The Model}

In this section I propose an empirical model to study the dynamics of individual earnings over time, within a job and over the career of a worker in one or more different jobs. 


\subsection{Basic Specification}

Building on the autoregressive model developed in Lillard and Willis (1978), for a worker $i$ and time $t$, I consider the following more general specification

$$
y_{i t}=\alpha y_{i t-1}+\beta d_{i t-1} y_{i t-1}+\mu_{i}+\phi_{i(t)}+\epsilon_{i t} ;\left(t=2, . ., T_{i}\right),
$$

where $\left\{y_{i 1}, \ldots, y_{i T_{i}-1}\right\}_{i=1}^{N}$ are the observed log earnings data, $d_{i t}$ is an indicator of working $i$ ending current job ${ }^{12}$ at time $t$, the parameter $\alpha$ or, alternatively, $\alpha+\beta$ measures the persistence on the level of those earnings to shocks, $\epsilon_{i t}$ is a purely transitory component, $\mu_{i}$ is an unobserved time-invariant individual component, like ability, and $\phi_{i(t)}$ is an unobserved individual-job component, such that,

- it remains constant whithin a position: $\phi_{i(t)}=\phi_{i(t-1)}$ if $d_{i t-1}=0$, but

- it is different across jobs: $\phi_{i(t)} \neq \phi_{i(t-1)}$ if $d_{i t-1}=1$.

In particular, for a worker $i$ that is observed for $T_{i}$ periods always at the same job, the model would be the classical $A R(1)$ process with individual fixed effects

$$
y_{i t}=\alpha y_{i t-1}+\mu_{i}+\phi_{i}+\epsilon_{i t}=\alpha y_{i t-1}+\eta_{i}+\epsilon_{i t} .
$$

Notice that I abstract from additive aggregate effects by regarding $y_{i t}$ as a deviation from a time effect $^{13}$.

The model in (1) departs from the standard one in two main features related to job mobility:

1. The dynamics captured by the autoregressive parameters is different in years when workers change job, $\alpha+\beta$, than within the same job, $\alpha$.

2. The unobserved heterogeneity across individuals has a job-specific matching component. In other words, I consider individual and job specific effects, $\mu_{i}+\phi_{i(t)}$.

\footnotetext{
${ }^{12}$ I should formally have a $j$ subscript for job on wages but since it does not add clarity I have dropped it.

${ }^{13} \mathrm{As}$ is usual in the earnings dynamics literature, the variable $y_{i t}$ - strictly speaking - represents log earnings residuals from first stage regressions on some observed variables -apart from year dummies (that capture the aggregate conditions of the economy) - as age, race and other individual characteristics. So we would keep in mind the following structure:

$$
\begin{aligned}
w_{i t} & =x_{i t} \beta+u_{i t} \\
u_{i t} & =\gamma_{i}+v_{i t} \\
v_{i t} & =\alpha v_{i t-1}+\epsilon_{i t}
\end{aligned}
$$

where $w_{i t}$ is the $\log$ annual wages of an individual $i$ in period $t, x_{i t}$ is a vector of exogenous variables, and $u_{i t}$ is a random error with two components, an unobserved individual heterogeneity component and an autoregressive component. The connection with the specification above would be $y_{i t}=\hat{u}_{i t}$ and $\eta_{i}=(1-\alpha) \gamma_{i}$.
} 
Given the model, within job, the transitory shocks will be uncorrelated with lagged earnings, but not with present or future earnings. Similarly, I do not need to assume the strict exogeneity of the job changes, in the sense of being uncorrelated to past, present, and future time-varying shocks. Apart from possibly being correlated with the unobserved heterogeneity components, I will consider that job changes may be predetermined, that is, they might be correlated with errors at certain periods but not at others. In particular, we could think of $d_{i t}$ as a function of the past errors and individual observed and unobserved characteristics - that is, the individual's work history - but as being uncorrelated to present and future shocks. Formally, I am imposing that

$$
E\left(\epsilon_{i t} \mid y_{i}^{t-1}, d_{i}^{t}\right)=0 .{ }^{14}
$$

Although it would be preferable to also allow for correlation between $d_{i t}$ and $\epsilon_{i t}$, that would lead us to consider selection models which is out of the scope of the paper. Even so, the model proposed here has several advantages. First, it permits the estimation of a specification in which job changes can be correlated with individual and job specific characteristics with no need to explicitly model the job mobility process or to do any assumption regarding the distribution of these individual and job effects. Moreover, note that neither time series or conditional heteroskedasticity are assumed. Therefore, as before, we could consider unobserved heterogeneity components in those conditional variances, both at the individual and job-specific level.

\subsection{Specification by Type of Exit}

In the empirical analysis I will also consider an extended specification that reflects different dynamics across individuals and time according to the type of job change

$$
y_{i t}=\alpha y_{i t-1}+\beta_{l} d_{i t-1}^{\text {loss }} y_{i t-1}+\beta_{q} d_{i t-1}^{q u i t} y_{i t-1}+\mu_{i}+\phi_{i(t)}+\epsilon_{i t},
$$

where $d_{i t}^{\text {loss }}$ is a dummy variable equal to one if worker $i$ at time $t$ ends current job due to an involuntary job separation or job loss; and $d_{i t}^{q u i t}$ equal one if worker $i$ at time $t$ ends current job because she has decided to moved to a new job.

I consider the kind of individual and stochastic effects which preserve the same properties as the basic specification.

\footnotetext{
${ }^{14}$ In the sequel, for any random variable (or vector of variables) $Z, z_{i t}$ denotes observation for individual $i$ at period $t$, and $z_{i}^{t}=\left\{z_{i 1}, \ldots, z_{i t}\right\}$, i.e. the set of observations for individual $i$ from the first period to period $t$.
} 


\section{Identification and Estimation Method}

In this section I discuss the conditions under which I achieve parameter identification. In the model, wages are observed conditional on individuals working; within-job wages, which identifies the parameter $\alpha$, are only observed if the individual does not change job; between-job wage growth, which helps to identify differences on dynamics on years of change, $\beta$, is observed only for job movers. Further, participation and mobility decisions can be all endogenous and if this is ignored we risk biasing the estimates of the model ${ }^{15}$. Regarding participation, given the type of individuals considered in the sample, it does not seem such a big issue in this setting so I will ignore it. The potential endogeneity of job mobility is circumvented by controlling for possibly correlated individual and job-specific heterogeneity, without observing it, and by means of a instrument variable estimation method ${ }^{16}$.

\subsection{Orthogonality Conditions}

As a matter of notation, I assume that the first observation occurs at $t=1$, so that the earnings equation (1) rewritten in first differences is defined from $t=3$

$$
\Delta y_{i t}=\alpha \Delta y_{i t-1}+\beta \Delta\left(d_{i t-1} y_{i t-1}\right)+\left(\phi_{i(t)}-\phi_{i(t-1)}\right)+\Delta \epsilon_{i t} ;\left(i=1, \ldots N ; t=3, . ., T_{i}\right) .
$$

Given (2), the following moment conditions hold

$$
E\left(y_{i}^{t-2}\left(1-d_{i t-1}\right) \Delta \epsilon_{i t}\right)=0 ; \quad\left(t=3, . ., T_{i}\right),
$$

and so

$$
E\left(y_{i}^{t-2}\left(1-d_{i t-1}\right)\left(\Delta y_{i t}-\alpha \Delta y_{i t-1}-\beta \Delta\left(d_{i t-1} y_{i t-1}\right)\right)\right)=0 .
$$

Then, we can consider a GMM estimator for $\theta=(\alpha, \beta)^{\prime}$ that used all the available lags at each period as instruments for the equations in first differences (Holtz-Eakin, Newey, and Rosen, 1988; Arellano and Bond, 1991). Notice that GMM estimation will only consider the moment conditions with $d_{i t-1}=0$, and that $\beta$ would be identified thanks to those with $d_{i t-1}=0$ but $d_{i t-2}=1$.

\footnotetext{
${ }^{15}$ As pointed out by Low et al. (2008) this, implicitly, has been the assumption made in papers estimating the covariance structure of earnings (MaCurdy, 1982; Abowd and Card, 1989; Meghir and Pistaferri, 2004).

${ }^{16}$ Low et al. (2008) use a similar sample selection procedure and consider a specification for the wage process fully parametric. Given the distributional assumption, in the estimation they control for selection into employment and for job mobility using the Heckman 2-step method. They claim that: "It is clear that what really matters is the firm mobility decision. Indeed, neglecting the participation correction reduces the variances of interest but the effects are minuscule."
} 


\subsection{GMM Estimation}

The GMM estimator of $\theta$ based on the corresponding sample moments for (4) with weight matrix $A_{N}$ is given by

$$
\hat{\theta}_{G M M}=\arg \min _{\theta}\left[\sum_{i=1}^{N} \Delta v_{i}^{\prime} Z_{i}\right] A_{N}\left[\sum_{i=1}^{N} Z_{i}^{\prime} \Delta v_{i}\right]
$$

where $v_{i}=y_{i}-W_{i} \theta$, with $y_{i}=\left(y_{i 3}, \ldots, y_{i T_{i}}\right)^{\prime}, W_{i}=\left(\begin{array}{cc}y_{i 2} & d_{i 2} y_{i 2} \\ \vdots & \vdots \\ y_{i T_{i}-1} & d_{i T_{i}-1} y_{i T_{i}-1}\end{array}\right)$, and

$$
Z_{i}=\left(\begin{array}{ccc}
y_{i 1}\left(1-d_{i 2}\right) & & 0 \\
& \left(y_{i 1}, y_{i 2}\right)\left(1-d_{i 3}\right) & \\
& \ddots & \\
0 & & \left(y_{i 1}, \ldots, y_{i T_{i}-2}\right)\left(1-d_{i T_{i}-1}\right)
\end{array}\right)
$$

According to standard GMM theory, an optimal choice of the inverse weight matrix, $V_{N}=A_{N}^{-1}$, is a consistent estimate of the covariance matrix of the orthogonality conditions $E\left(Z_{i}^{\prime} \Delta v_{i} \Delta v_{i}^{\prime} Z_{i}\right)$. A one-step GMM estimator uses

$$
\hat{V}=\sum_{i=1}^{N} Z_{i}^{\prime} D D^{\prime} Z_{i}
$$

where $D$ is the first-difference matrix operator, and a two-step GMM estimator uses the robust choice

$$
\tilde{V}=\sum_{i=1}^{N} Z_{i}^{\prime} \Delta \hat{v}_{i} \Delta \hat{v}_{i}^{\prime} Z_{i}
$$

where $\Delta \hat{v}_{i}$ are one-step residuals.

An estimate of the asymptotic variance of two-step GMM is given by

$$
\widehat{\operatorname{Var}}\left(\hat{\theta}_{G M M 2}\right)=\left[\left(\sum_{i=1}^{N} \Delta W_{i}^{\prime} Z_{i}\right) \tilde{V}^{-1}\left(\sum_{i=1}^{N} Z_{i}^{\prime} \Delta W_{i}\right)\right]^{-1} .
$$

\section{Estimation Results}

In this section I show the results corresponding to the GMM estimation of the specifications presented in Section 3 (equations 1 and 3). In the estimation, $y_{i t}$ are log annual real wages residuals from first stage regressions on year dummies, age, education, dummies for race, region of residence, and residence in a $\operatorname{SMSA}^{17}$.

\footnotetext{
${ }^{17}$ In earnings dynamics research it is standard to adopt a two step procedure. In the first stage regression, the log of real wages is regressed on control variables and year dummies to eliminate group heterogeneities and aggregate time effects. Then, in the second stage, the unobserved heterogeneity and dynamics of the residuals are modelled.
} 


\subsection{Common Parameters Estimates}

I begin by obtaining alternative estimates of a univariate $\mathrm{AR}(1)$ model (setting $\beta=0$ ). Table 5 compares OLS in levels, first differences, and within- groups with those obtaining by GMM, using as instruments for the equation in first differences of the lags of wages up to $t-2$.

Table 5. Autorregresive Model of Earnings

\begin{tabular}{lccccccc}
\hline & $\begin{array}{c}\text { OLS } \\
\text { levels }\end{array}$ & $\begin{array}{c}\text { OLS } \\
\text { dif }\end{array}$ & WG & GMM1 & GMM2 & $\begin{array}{c}\text { GMM } \\
\text { System }\end{array}$ & $\begin{array}{c}\text { GMM2 } \\
\text { AR(2) }\end{array}$ \\
\hline \hline$y_{i t-1}$ & 0.792 & -0.313 & 0.389 & 0.331 & 0.321 & 0.431 & 0.329 \\
& $(0.009)$ & $(0.012)$ & $(0.006)$ & $(0.023)$ & $(0.022)$ & $(0.020)$ & $(0.025)$ \\
$y_{i t-2}$ & & & & & & & 0.048 \\
& & & & & & & $(0.014)$ \\
m1 & - & - & - & $17.25^{*}$ & $-14.55^{*}$ & $-15.58^{*}$ & $-13.83^{*}$ \\
m2 & - & - & - & $2.09^{*}$ & 1.80 & $2.91^{*}$ & -0.15 \\
Sargan test & - & - & - & - & 304.02 & $369.18^{*}$ & 295.48 \\
(df) & & & & & $(275)$ & $(298)$ & $(273)$ \\
\hline
\end{tabular}

Note: Heteroskedasticity robust standard errors in parentheses. $\mathrm{m} 1$ and $\mathrm{m} 2$ are serial correlation tests for differenced errors. ${ }^{*}$ Rejection at the 5 percent.

Taking GMM as a benchmark (columns 4 and 5), OLS in levels is biased upward and OLS in differences biased downward, as we would expect for an AR data generating process with individual unobserved heterogeneity. However, the comparison with the WG is puzzling, since we would also expect a downward bias in that case. Although the system- GMM estimate is bigger than WG, the Sargan test rejects the mean stationarity. Finally, the two-step $\operatorname{AR}(2)$ estimates reported in the last column do not change the conclusions, that suggests misspecification as a likely reason for these results ${ }^{18}$.

Model in equation (1) differs from the previous standard $\operatorname{AR}(1)$ model in two main aspects: the different dynamics within and between jobs and the individual-job specific unobserved heterogeneity. The first two columns in Table 6 report GMM estimates (one- and two-step) of the basic specification, and column 3 corresponds to the two-step GMM estimates of the specification by type of exit. For comparison, I also include GMM estimates for a specification setting $\beta=0$ (column 4) and another ignoring job-specific heterogeneity (column 5).

\footnotetext{
${ }^{18}$ These results are in line with the ones in Alvarez and Arellano (2004).
} 
Table 6. Autorregresive Model of Earnings with Job Changes

\begin{tabular}{lccccc}
\hline & $\begin{array}{c}\text { GMM1 } \\
\text { Basic }\end{array}$ & $\begin{array}{c}\text { GMM2 } \\
\text { Basic }\end{array}$ & $\begin{array}{c}\text { GMM2 } \\
\text { By type } \\
\text { of exit }\end{array}$ & $\begin{array}{c}\text { GMM2 } \\
\text { Same dynamics } \\
\text { within and across }\end{array}$ & $\begin{array}{c}\text { GMM2 } \\
\text { No job-specific } \\
\text { heterogeneity }\end{array}$ \\
\hline \hline$y_{i t-1}$ & 0.060 & 0.026 & 0.018 & 0.149 & 0.272 \\
$d_{i t-1} y_{i t-1}$ & 0.133 & 0.153 & & $(0.021)$ & $(0.048)$ \\
& $(0.051)$ & $(0.049)$ & & & 0.096 \\
$d_{i t-1}^{\text {loss }} y_{i t-1}$ & & & 0.175 & & $(0.086)$ \\
$d_{i t-1}^{\text {quit }} y_{i t-1}$ & & & $(0.083)$ & & \\
m1 & & & 0.161 & & \\
m2 & $-7.52^{*}$ & $-7.32^{*}$ & $-7.02^{*}$ & $-12.51^{*}$ & $-14.24^{*}$ \\
Sargan test & -0.42 & -0.76 & -0.76 & 0.35 & 1.72 \\
(df) & - & 292.38 & 291.25 & 297.59 & 301.09 \\
\hline
\end{tabular}

Note: robust t-ratios in parentheses. $\mathrm{m} 1$ and $\mathrm{m} 2$ are serial correlation tests for differenced errors. * Rejection at the 5 percent.

Controlling for individual and job-specific effects, GMM estimates of the AR coefficient within groups, $\alpha$, are almost zero; and across jobs, $\beta$, is significant but small (columns 1 and 2). The corresponding estimates for the AR coefficients when I distinguish between involuntary, $\beta_{l}$, and voluntary changes, $\beta_{q}$, are very close to each other (the difference is statistically insignificant). If I impose the same dynamics, both within and between jobs, but still allowing for individual and job-specific effects, the $\hat{\alpha}$ estimate increases capturing the effect of job mobility (column 4). Finally, if I ignore the possibility of heterogeneous match effects across jobs the results for $\hat{\alpha}$ and $\hat{\beta}$ show a marked discrepancy between columns 5 and 2 (my preferred specification). Although it is not possible to reject the latter specification in terms of the Sargan test, the variance estimates in the next section suggest that individual heterogeneity across jobs is not negligible for movers, that is, individuals who change job at least once in the sample.

\section{$5.2 \quad$ Variance estimates}

Optimal estimation of $\sigma_{\mu}^{2}$ and $\sigma_{\phi}^{2}$ requires consideration of the data covariance structure. The errors in levels, $v_{i t}=\mu_{i}+\phi_{i(t)}+\epsilon_{i t}$, satisfy

$$
\begin{aligned}
\operatorname{Var}\left(v_{i t}\right) & =\operatorname{Var}\left(\mu_{i}+\phi_{i(t)}\right)+\sigma_{t}^{2}, \text { and } \\
\operatorname{Cov}\left(v_{i t}, v_{i s}\right) & =\operatorname{Cov}\left(\mu_{i}+\phi_{i(t)}, \mu_{i}+\phi_{i(s)}\right) .
\end{aligned}
$$

If we assume no sorting, that is, once we have controlled for $\mu_{i}$ it would not make much sense to 
consider correlations across jobs and correlations between individual and job effects, errors would satisfy

$$
\begin{aligned}
\operatorname{Var}\left(v_{i t}\right) & =\sigma_{\mu}^{2}+\sigma_{\phi}^{2}+\sigma_{t}^{2}, \text { and } \\
\operatorname{Cov}\left(v_{i t}, v_{i s}\right) & = \begin{cases}\sigma_{\mu}^{2}+\sigma_{\phi}^{2} & \text { if same job at time } t \neq s, \\
\sigma_{\mu}^{2} & \text { if different job at time } t \neq s .\end{cases}
\end{aligned}
$$

Therefore, for large $N$ simple consistent estimates can be obtained combining cross-sectional sample covariances as

$$
\left(\widehat{\sigma_{\mu}^{2}+\sigma_{\phi}^{2}}\right)=\sum_{r=1}^{T-2}\left[\frac{1}{T-r-1} \sum_{t=r+2}^{T} \frac{1}{\sum_{i=1}^{N} S_{i t r}} \sum_{i=1}^{N} S_{i t r} \hat{v}_{i t} \hat{v}_{i t-r}\right],
$$

and

$$
\widehat{\sigma}_{\mu}^{2}=\sum_{r=1}^{T-2}\left[\frac{1}{T-r-1} \sum_{t=r+2}^{T} \frac{1}{\sum_{i=1}^{N}\left(1-S_{i t r}\right)} \sum_{i=1}^{N}\left(1-S_{i t r}\right) \hat{v}_{i t} \hat{v}_{i t-r}\right],
$$

where $S_{i t r}=\prod_{s=1}^{r}\left(1-d_{i t-s}\right)=\left(1-d_{i t-1}\right) \cdot\left(1-d_{i t-2}\right) \cdot \ldots \cdot\left(1-d_{i t-r}\right)$ indicates that individual $i$ stays at the same job between $t-r$ and $t$, and $\hat{v}_{i t}=y_{i t}-\hat{\alpha} y_{i t-1}-\hat{\beta} d_{i t-1} y_{i t-1}$.

Results are reported in Table 7. I find that in the whole sample (column 1) the estimated variance of the individual effects is 0.09 , very close to the variance of the sum of these and the job-specific effects, mainly because for the stayers (people who never change job) it is not possible to discriminate among those two components (column 2). If I only consider individuals that change at least once (column 3 ), the estimated variance of the job-specific effects represents around one third of the variance for the individual fixed effects. Finally, if I only use those who suffer involuntary job changes (column 4) the estimated variance of the heterogeneity across jobs increases up to one half ${ }^{19}$.

Table 7. Wage Variance Estimates

\begin{tabular}{lcccc}
\hline & $\begin{array}{c}\text { Whole } \\
\text { sample }\end{array}$ & $\begin{array}{c}\text { Only } \\
\text { stayers }\end{array}$ & $\begin{array}{c}\text { Only } \\
\text { movers }\end{array}$ & $\begin{array}{c}\text { Only } \\
\text { layoffs }\end{array}$ \\
\hline \hline$\left(\sigma_{\mu}^{2}+\sigma_{\phi}^{2}\right)$ & 0.104 & 0.094 & 0.124 & 0.156 \\
$\sigma_{\mu}^{2}$ & 0.090 & - & 0.091 & 0.104 \\
$\sigma_{\phi}^{2}$ & 0.014 & - & 0.033 & 0.052 \\
\hline Obs. & 19,069 & 9,064 & 10,005 & 2,014 \\
\hline Note: $\sigma_{\mu}^{2}$ and $\sigma_{\phi}^{2}$ are the variances of the individual and job \\
effect. $\hat{\sigma}_{\phi}^{2}$ is obtained as the difference between $\left(\sigma_{\mu}^{2}+\sigma_{\phi}^{2}\right)$ \\
and $\hat{\sigma}_{\mu}^{2}$. Obs.: number of sample $\hat{u}_{i t}$ available for calculation. \\
I drop observations if consecutive changes for the same worker, \\
and any sample covariance with less than 25 observations.
\end{tabular}

\footnotetext{
${ }^{19}$ Similar results are found in Berry et al. (1988).
} 


\section{Conclusions}

This paper develops an error components model designed to more thoroughly describe the impact of job mobility on the dynamics and heterogeneity of individual wages than previous references. In particular, the specification proposed has two different parameters to capture dynamics within jobs and across jobs, and the unobserved heterogeneity shows a richer pattern, as well, composed of both individual and jobspecific effects. The potential endogeneity of job mobility in relation to earnings is circumvented using an instrument variable estimation method that controls for those unobserved heterogeneity components.

In the data, drawn from the PSID, I find that - once we control for individual and job-specific effects - the dynamics within jobs is almost zero, whereas across jobs is significant but small. For the dynamics, the distinction between voluntary and involuntary transitions turns out to be irrelevant. However, that distinction matters in the case of the components of the cross-sectional variance. The estimated variance of the job-specific effects represents around one third of the variance for the individual fixed effects. If I consider a subsample that only includes involuntary job changes, the estimated variance of the heterogeneity across jobs increases up to one half.

Further research is needed on the consideration in the model of the labour market participation decision and, thus, the inclusion of women and transitions job-to-nonemployment and nonemploymentto-job into the analysis. 


\section{APPENDICES}

\section{A Sample selection}

Starting point: PSID 1968-1993 Family and Individual - merged files (53,005 individuals).

1. Drop members of the Latino sample (10,022 individuals $)=$ Sample $(42,983$ individuals $)$.

2. Keep only those who are continuously heads of their households $=$ Sample (16,038 individuals).

3. Keep only males aged 25 to 55 over the period $=$ Sample (8,190 individuals).

4. Drop those with a spell of self-employment $=$ Sample (6,303 individuals).

5. Drop those with missing race, education and region of residence records $=$ Sample $(6,047$ individuals).

6. Drop those with top-coded earnings records and those with missing earnings $=$ Sample $(5,479$ individuals).

7. Drop those with outlying earnings records, that is, a change in log earnings greater than 5 or less than $-3=$ Sample $(5,384$ individuals $)$.

8. Drop those with missing records on reason of job change question and those with noncontinuous data $=$ Sample $(5,345$ individuals $)$.

9. Keep only those who are in the sample for 8 years or more

= FINAL SAMPLE: Males, 1968-1992 (2,013 individuals and 27,845 observations). 


\section{B Sample composition and descriptive statistics}

\begin{tabular}{cccc}
\multicolumn{4}{c}{ Table B.1. Distribution of observations by year } \\
\hline Year & $\begin{array}{c}\text { Number of } \\
\text { observations }\end{array}$ & Year & $\begin{array}{c}\text { Number of } \\
\text { observations }\end{array}$ \\
\hline \hline 1968 & 613 & 1981 & 1,287 \\
1969 & 668 & 1982 & 1,330 \\
1970 & 726 & 1983 & 1,343 \\
1971 & 762 & 1984 & 1,393 \\
1972 & 815 & 1985 & 1,451 \\
1973 & 885 & 1986 & 1,400 \\
1974 & 965 & 1987 & 1,353 \\
1975 & 1,046 & 1988 & 1,302 \\
1976 & 1,072 & 1989 & 1,258 \\
1977 & 1,104 & 1990 & 1,205 \\
1978 & 1,146 & 1991 & 1,173 \\
1979 & 1,201 & 1992 & 1,096 \\
1980 & 1,251 & & \\
\hline
\end{tabular}

Table B.2. Distribution of individuals by number of observations

\begin{tabular}{|c|c|c|c|c|}
\hline $\begin{array}{l}\text { Number } \\
\text { of Years }\end{array}$ & \multicolumn{2}{|c|}{$\begin{array}{l}\text { Number of } \\
\text { Individuals }\end{array}$} & $\begin{array}{l}\text { Number } \\
\text { of Years }\end{array}$ & $\begin{array}{c}\text { Number } \\
\text { Individuals }\end{array}$ \\
\hline 8 & \multicolumn{2}{|c|}{245} & 17 & 84 \\
\hline 9 & \multicolumn{2}{|c|}{211} & 18 & 84 \\
\hline 10 & \multicolumn{2}{|c|}{153} & 19 & 79 \\
\hline 11 & \multicolumn{2}{|c|}{179} & 20 & 68 \\
\hline 12 & \multicolumn{2}{|c|}{143} & 21 & 54 \\
\hline 13 & \multicolumn{2}{|c|}{151} & 22 & 35 \\
\hline 14 & \multicolumn{2}{|c|}{150} & 23 & 41 \\
\hline 15 & \multicolumn{2}{|c|}{130} & 24 & 32 \\
\hline 16 & \multicolumn{2}{|c|}{112} & 25 & 62 \\
\hline \multicolumn{5}{|c|}{ Table B.3. Descriptive Statistics } \\
\hline \multicolumn{3}{|c|}{1968} & 1980 & 1992 \\
\hline \multicolumn{2}{|c|}{ Age } & $\begin{array}{l}37.16 \\
(6.33)\end{array}$ & $\begin{array}{l}36.58 \\
(8.82)\end{array}$ & $\begin{array}{l}40.48 \\
(5.70)\end{array}$ \\
\hline \multicolumn{2}{|c|}{ HS Dropout } & 0.45 & 0.26 & 0.12 \\
\hline \multicolumn{2}{|c|}{ HS Graduate } & 0.40 & 0.55 & 0.61 \\
\hline \multicolumn{2}{|c|}{ Hours } & $\begin{array}{c}2,272 \\
(524)\end{array}$ & $\begin{array}{c}2,149 \\
(502)\end{array}$ & $\begin{array}{l}2,197 \\
(489)\end{array}$ \\
\hline \multicolumn{2}{|c|}{ Married } & 0.74 & 0.80 & 0.86 \\
\hline \multicolumn{2}{|c|}{ White } & 0.66 & 0.64 & 0.69 \\
\hline \multicolumn{2}{|c|}{ \# Children } & $\begin{array}{c}2.83 \\
(2.08)\end{array}$ & $\begin{array}{c}1.45 \\
(1.32)\end{array}$ & $\begin{array}{c}1.44 \\
(1.19)\end{array}$ \\
\hline \multicolumn{2}{|c|}{ Family Size } & $\begin{array}{c}4.95 \\
(2.03)\end{array}$ & $\begin{array}{c}3.60 \\
(1.66)\end{array}$ & $\begin{array}{c}3.56 \\
(1.38)\end{array}$ \\
\hline \multicolumn{2}{|c|}{ North-East } & 0.18 & 0.16 & 0.17 \\
\hline \multicolumn{2}{|c|}{ North-Central } & 0.26 & 0.24 & 0.23 \\
\hline \multicolumn{2}{|c|}{ South } & 0.42 & 0.46 & 0.44 \\
\hline \multicolumn{2}{|l|}{ SMSA } & 0.69 & 0.66 & 0.54 \\
\hline
\end{tabular}

Note: Standard deviations of non-binary variables

in parentheses. 


\section{References}

[1] ABOWD, J. M., and D. CARD (1989). "On the Covariance Structure of Earnings and Hours Changes", Econometrica, 57, pp. 441-445.

[2] ABOWD, J. M., and C. KANG (2002). Simultaneous Determination of Wage Rates and Tenure, unpublished manuscript.

[3] ABOWD, J. M., F. KRAMARZ and D. N. MARGOLIS (1999). "High Wage Workers and High Wage Firms", Econometrica, 67, pp. 251-333.

[4] ALTONJI, J., and R. SHAKOTKO (1987). "Do wages rise with job seniority?", Review of Economic Studies, 54, pp. 437-459.

[5] AltonJI, J., and N. WiLliams (1997). Do Wages Rise with Job Seniority? A Reassessment, NBER Working Paper No. 6010. Revised version (2005) in the Industrial and Labor Relations Review, 58, pp. 370-397.

[6] ÁLVAREZ, J., and M. ARELLANO (2004). Robust Likelihood Estimation of Dynamic Panel Data Models, CEMFI Working Paper 0421.

[7] AMMAN, R. A., and T. J. KLEIN (2007). Returns to Type or Tenure?, IZA Discussion Paper 2773.

[8] ARELlanO, M., and S. BOND (1991). "Some tests of specification for panel data: Monte Carlo Evidence and an Application to Employment Equations", Review of Economic Studies, 58, pp. $277-297$.

[9] BAGGER, J. (2007). Early Career Wage Profiles and Mobility Premiums, unpublished manuscript.

[10] BECKER, G. S. (1975). Human Capital: A Theoretical and Empirical Analysis, Second Edition, New York: NBER and Columbia University Press.

[11] BERRY, S., P. GOTTSCHALK and D. WISSOKER (1988). "An Error Components Model of the Impact of Plant Closing on Earnings", Review of Economics and Statistics, 70, pp. 701-707.

[12] BONHOMME, S., and G. JOLIVET (2006). The Pervasive Absence of Compensating Differentials, unpublished manuscript.

[13] BROWN, J. N., and A. LIGHT (1992). "Interpreting Panel Data on Job Tenure", Journal of Labor Economics, 10, pp. 219-257.

[14] BURDETT, K. (1978). "Theory of Employer Job Search and Quit Rates", American Economic Review, 68, pp. 212-220. 
[15] CHAMBERlain, G., and K. HIRANO (1999). "Predictive Distributions Based on Longitudinal Earnings Data", Annales d'Economie et de Statistique, No. 55-56, pp. 211-242.

[16] DUSTMANN, C., and C. MEGHIR (2005). "Wages, Experience and Seniority", Review of Economic Studies, 72, pp. 77-108.

[17] GOTTSCHALK, P., and R. MOFFITT (1994). "The Growth of Earnings Instability in the U.S. Labor Market", Brookings Papers on Economic Activity, 2, pp. 217-272.

[18] HOLTZ-EAKIN, D., W. NEWEY and H. ROSEN (1988). "Estimating Vector Autoregressions with Panel Data", Econometrica, 56, pp. 1371-1395.

[19] HOSPIDO, L. (2009). Modelling Heterogeneity and Dynamics in the Volatility of Individual Wages, unpublished manuscript.

[20] JOHnSON, W. R. (1978). "A Theory of Job Shopping", Quarterly Journal of Economics, 92, pp. 261-278.

[21] JOVANOVIC, B. (1979). "Firm-Specific Capital and Turnover", Journal of Political Economy, 87, pp. 1246-1260.

[22] JUHN, C., K. M. MURPHY and B. PIERCE (1993). "Wage Inequality and the Rise in Returns to Skill", Journal of Political Economy, 101, pp. 410-442.

[23] KIM, Y.-S., T. LOUP, J. LUPTON and F. P. STAFFORD (2000). Notes on the 'Income Plus' Files: 1994-1997 Family Income and Components Files, available at . http://psidonline.isr.umich.edu/Publications/Papers/y_pls_notes.pdf.

[24] LEONARDI, M. (2003). Earnings Instability of Job Stayers and Job Changers, IZA Discussion Paper 946.

[25] LILLARD, L. A. (1999). "Job turnover heterogeneity and person-job-specific time-series wages", Annales d'Economie et de Statistique, 55-56, pp. 183-210.

[26] LILLARD, L. A., and R. J. WILLIS (1978). "Dynamic Aspects of Earnings Mobility", Econometrica, 46, pp. 985-1012.

[27] LOW, H., C. MEGHIR and L. PISTAFERRI (2008). Wage Risk and Employment Risk over the Life Cycle, IZA Discussion Paper 3700.

[28] MACURDY, T. E. (1982). "The Use of Time-Series Processes to Model the Error Structure of Earnings in Longitudinal Data Analysis", Journal of Econometrics, 18, pp. 83-114. 
[29] MARSHALL, R., and G. ZARKIN (1987). "The effect of job tenure on wage offers", Journal of Labor Economics, 5, pp. 301-324.

[30] MEGHIR, C., and L. PISTAFERRI (2004). "Income variance dynamics and heterogeneity", Econometrica, 72 , pp. 1-32.

[31] MOFFITT, R., and P. GOTTSCHALK (1995). Trends in the Covariance Structure of Earnings in the United States, 1969-1987, unpublished manuscript.

[32] NEAL, D. (1995). "Industry-Specific Human Capital: Evidence from Displaced Workers", Journal of Labor Economics, 13, pp. 653-677.

[33] POLSKY, D. (1999). "Changing Consequences of Job Separation in the United States", Industrial and Labor Relations Review, 52, pp. 565-580.

[34] POSTEL-VINAY, F., and J.-M. ROBIN (2002). "Equilibrium Wage Dispersion with Heterogeneous Workers and Firms", Econometrica, 70, pp. 2295-1350.

[35] ROSEN, S. (1972). "Learning by experience as joint production", Quarterly Journal of Economics, 86, pp. 366-382.

[36] STEVENS, A. H. (2001). "Changes in Earnings Instability and Job Loss", Industrial and Labor Relations Review, 55, pp. 60-78.

[37] TOPEL, R. (1986). "Job mobility, search, and earnings growth: A reinterpretation of human capital earnings functions", Research in Labor Economics, 8, pp. 199-233.

[38] — (1991). "Specific capital, mobility and wages: Wages rise with job seniority", Journal of Political Economy, 99, pp. 145-176.

[39] TOPEL, R. H., and M. P. WARD (1992). "Job Mobility and the Careers of Young Men", Quarterly Journal of Economics, 107(2), pp. 439-479. 


\section{BANCO DE ESPAÑA PUBLICATIONS}

\section{WORKING PAPERS ${ }^{1}$}

0722 MARTÍN VALLCORBA AND JAVIER DELGADO: Determinantes de la morosidad bancaria en una economía dolarizada. El caso uruguayo.

0723 ANTÓN NÁKOV AND ANDREA PESCATORI: Inflation-output gap trade-off with a dominant oil supplier.

0724 JUAN AYUSO, JUAN F. JIMENO AND ERNESTO VILLANUEVA: The effects of the introduction of tax incentives on retirement savings.

0725 DONATO MASCIANDARO, MARÍA J. NIETO AND HENRIETTE PRAST: Financial governance of banking supervision

0726 LUIS GUTIÉRREZ DE ROZAS: Testing for competition in the Spanish banking industry: The Panzar-Rosse approach revisited.

0727 LUCÍA CUADRO SÁEZ, MARCEL FRATZSCHER AND CHRISTIAN THIMANN: The transmission of emerging market shocks to global equity markets.

0728 AGUSTÍN MARAVALL AND ANA DEL RÍO: Temporal aggregation, systematic sampling, and the Hodrick Prescott filter.

0729 LUIS J. ÁLVAREZ: What do micro price data tell us on the validity of the New Keynesian Phillips Curve?

0730 ALFREDO MARTÍN-OLIVER AND VICENTE SALAS-FUMÁS: How do intangible assets create economic value? An application to banks.

0731 REBECA JIMÉNEZ-RODRÍGUEZ: The industrial impact of oil price shocks: Evidence from the industries of six OECD countries.

0732 PILAR CUADRADO, AITOR LACUESTA, JOSÉ MARÍA MARTíNEZ AND EDUARDO PÉREZ: El futuro de la tasa de actividad española: un enfoque generacional.

0733 PALOMA ACEVEDO, ENRIQUE ALBEROLA AND CARMEN BROTO: Local debt expansion... vulnerability reduction? An assessment for six crises-prone countries.

0734 PEDRO ALBARRÁN, RAQUEL CARRASCO AND MAITE MARTÍNEZ-GRANADO: Inequality for wage earners and self-employed: Evidence from panel data.0735 ANTÓN NÁKOV AND ANDREA PESCATORI: Oil and the Great Moderation.

0736 MICHIEL VAN LEUVENSTEIJN, JACOB A. BIKKER, ADRIAN VAN RIXTEL AND CHRISTOFFER KOK-SØRENSEN: A new approach to measuring competition in the loan markets of the euro area.

0737 MARIO GARCÍA-FERREIRA AND ERNESTO VILLANUEVA: Employment risk and household formation: Evidence from differences in firing costs.

0738 LAURA HOSPIDO: Modelling heterogeneity and dynamics in the volatility of individual wages.

0739 PALOMA LÓPEZ-GARCÍA, SERGIO PUENTE AND ÁNGEL LUIS GÓMEZ: Firm productivity dynamics in Spain.

0740 ALFREDO MARTÍN-OLIVER AND VICENTE SALAS-FUMÁS: The output and profit contribution of information technology and advertising investments in banks.

0741 ÓSCAR ARCE: Price determinacy under non-Ricardian fiscal strategies.

0801 ENRIQUE BENITO: Size, growth and bank dynamics.

0802 RICARDO GIMENO AND JOSÉ MANUEL MARQUÉS: Uncertainty and the price of risk in a nominal convergence process.

0803 ISABEL ARGIMÓN AND PABLO HERNÁNDEZ DE COS: Los determinantes de los saldos presupuestarios de las Comunidades Autónomas.

0804 OLYMPIA BOVER: Wealth inequality and household structure: US vs. Spain.

0805 JAVIER ANDRÉS, J. DAVID LÓPEZ-SALIDO AND EDWARD NELSON: Money and the natural rate of interest: structural estimates for the United States and the euro area.

0806 CARLOS THOMAS: Search frictions, real rigidities and inflation dynamics.

0807 MAXIMO CAMACHO AND GABRIEL PEREZ-QUIROS: Introducing the EURO-STING: Short Term INdicator of Euro Area Growth.

0808 RUBÉN SEGURA-CAYUELA AND JOSEP M. VILARRUBIA: The effect of foreign service on trade volumes and trade partners.

0809 AITOR ERCE: A structural model of sovereign debt issuance: assessing the role of financial factors.

0810 ALICIA GARCÍA-HERRERO AND JUAN M. RUIZ: Do trade and financial linkages foster business cycle synchronization in a small economy?

0811 RUBÉN SEGURA-CAYUELA AND JOSEP M. VILARRUBIA: Uncertainty and entry into export markets.

0812 CARMEN BROTO AND ESTHER RUIZ: Testing for conditional heteroscedasticity in the components of inflation.

0813 JUAN J. DOLADO, MARCEL JANSEN AND JUAN F. JIMENO: On the job search in a model with heterogeneous jobs and workers.

0814 SAMUEL BENTOLILA, JUAN J. DOLADO AND JUAN F. JIMENO: Does immigration affect the Phillips curve? Some evidence for Spain.

0815 ÓSCAR J. ARCE AND J. DAVID LÓPEZ-SALIDO: Housing bubbles.

0816 GABRIEL JIMÉNEZ, VICENTE SALAS-FUMÁS AND JESÚS SAURINA: Organizational distance and use of collateral for business loans.

1. Previously published Working Papers are listed in the Banco de España publications catalogue. 
0817 CARMEN BROTO, JAVIER DÍAZ-CASSOU AND AITOR ERCE-DOMÍNGUEZ: Measuring and explaining the volatility of capital flows towards emerging countries.

0818 CARLOS THOMAS AND FRANCESCO ZANETTI: Labor market reform and price stability: an application to the Euro Area.

0819 DAVID G. MAYES, MARÍA J. NIETO AND LARRY WALL: Multiple safety net regulators and agency problems in the EU: Is Prompt Corrective Action partly the solution?

0820 CARMEN MARTÍNEZ-CARRASCAL AND ANNALISA FERRANDO: The impact of financial position on investment: an analysis for non-financial corporations in the euro area.

0821 GABRIEL JIMÉNEZ, JOSÉ A. LÓPEZ AND JESÚS SAURINA: Empirical analysis of corporate credit lines.

0822 RAMÓN MARÍA-DOLORES: Exchange rate pass through in New Member States and candidate countries of the EU.

0823 IGNACIO HERNANDO, MARÍA J. NIETO AND LARRY D. WALL: Determinants of domestic and cross-border bank acquisitions in the European Union

0824 JAMES COSTAIN AND ANTÓN NÁKOV: Price adjustments in a general model of state-dependent pricing.

0825 ALFREDO MARTÍN-OLIVER, VICENTE SALAS-FUMÁS AND JESÚS SAURINA: Search cost and price dispersion in vertically related markets: the case of bank loans and deposits.

0826 CARMEN BROTO: Inflation targeting in Latin America: Empirical analysis using GARCH models.

0827 RAMÓN MARÍA-DOLORES AND JESÚS VAZQUEZ: Term structure and the estimated monetary policy rule in the eurozone.

0828 MICHIEL VAN LEUVENSTEIJN, CHRISTOFFER KOK SØRENSEN, JACOB A. BIKKER AND ADRIAN VAN RIXTEL: Impact of bank competition on the interest rate pass-through in the euro area.

0829 CRISTINA BARCELÓ: The impact of alternative imputation methods on the measurement of income and wealth: Evidence from the Spanish survey of household finances.

0830 JAVIER ANDRÉS AND ÓSCAR ARCE: Banking competition, housing prices and macroeconomic stability.

0831 JAMES COSTAIN AND ANTÓN NÁKOV: Dynamics of the price distribution in a general model of state-dependent pricing.

0832 JUAN A. ROJAS: Social Security reform with imperfect substitution between less and more experienced workers

0833 GABRIEL JIMÉNEZ, STEVEN ONGENA, JOSÉ LUIS PEYDRÓ AND JESÚS SAURINA: Hazardous times for monetary policy: What do twenty-three million bank loans say about the effects of monetary policy on credit risktaking?

0834 ENRIQUE ALBEROLA AND JOSÉ MARÍA SERENA: Sovereign external assets and the resilience of global imbalances.

0835 AITOR LACUESTA, SERGIO PUENTE AND PILAR CUADRADO: Omitted variables in the measure of a labour quality index: the case of Spain.

0836 CHIARA COLUZZI, ANNALISA FERRANDO AND CARMEN MARTÍNEZ-CARRASCAL: Financing obstacles and growth:

An analysis for euro area non-financial corporations.

0837 ÓSCAR ARCE, JOSÉ MANUEL CAMPA AND ÁNGEL GAVILÁN: Asymmetric collateral requirements and output composition.

0838 ÁNGEL GAVILÁN AND JUAN A. ROJAS: Solving Portfolio Problems with the Smolyak-Parameterized Expectations Algorithm.

0901 PRAVEEN KUJAL AND JUAN RUIZ: International trade policy towards monopoly and oligopoly.

0902 CATIA BATISTA, AITOR LACUESTA AND PEDRO VICENTE: Micro evidence of the brain gain hypothesis: The case of Cape Verde.

0903 MARGARITA RUBIO: Fixed and variable-rate mortgages, business cycles and monetary policy.

0904 MARIO IZQUIERDO, AITOR LACUESTA AND RAQUEL VEGAS: Assimilation of immigrants in Spain: A longitudinal analysis.

0905 ÁNGEL ESTRADA: The mark-ups in the Spanish economy: international comparison and recent evolution.

0906 RICARDO GIMENO AND JOSÉ MANUEL MARQUÉS: Extraction of financial market expectations about inflation and interest rates from a liquid market.

0907 LAURA HOSPIDO: Job changes and individual-job specific wage dynamics.

\begin{tabular}{|r|c|}
\hline & Unidad de Publicaciones \\
BANCODEESPANA & Alcalá, 522; 28027 Madrid \\
Eurosistema & Telephone +34 91 338 6363. Fax +34913386488 \\
& e-mail: publicaciones@bde.es \\
www.bde.es
\end{tabular}

